\title{
Beuys, Hardt and Negri: One World - One Consciousness
}

\author{
By Alexandria Pierce*
}

\begin{abstract}
With the "Social Turn" in art, ideas proposed by Joseph Beuys (1918-1986) gain renewed currency. Today, Beuys's concept of Social Sculpture may be compared to what Michael Hardt and Antonio Negri define as the biopolitical because it produces relationships, networks and subjectivities. One of Beuys' platforms was democracy, defined by Hardt and Negri as the rule by all based on relationships of equality and freedom. For Hardt and Negri, democracy of the multitude is peace without war. Remarkably, in 2004 , they speculated on the rise of a new society based on blurring distinctions between the economic, the political, the social, and the cultural, subjects Beuys lectured on at length. Notably, Beuys abandoned his hermetic performances for direct action of thinking, molding thoughts into actions, and speaking out. Beuys' metaphor for human society as bees and the hive is re-registered by Hardt and Negri as "the common," a "swarm" or a united front determined by revolutionary will. Hardt and Negri propose that "the world is in an interregnum with economic wealth and power shifting." If Beuys can be seen as demarcating the beginning of this interregnum, do events such as The Arab Spring and Occupy Wall Street signify what Hardt and Negri predicted more than a decade ago, that, "time is split between a present that is already dead and a future that is already living..."? (Hardt \& Negri, 2004, p. 258) Like Beuys before him, Negri suggests that it is art - not reason - that stimulates imagination to realize consciousness of one united world.
\end{abstract}

\section{Consciousness, Love and Death}

While the link between art and politics characterizes the twentieth century, this duality returns as a force today. This essay will re-examine the environmental and political activism of German artist Joseph Beuys (1921-86), in relation to the theory of Michael Hardt (b. 1960) and Antonio Negri (b. 1933). It will be argued here that the goals of each of these thinkers are similar, and that with the 'social turn in art,' art and politics are center stage in the second decade of the twenty-first century. First published in 2009, Negri's book, Art and Multitude, stresses that "art should give ethical meaning...in which being-for-the-other - qua being-in-common - triumphs" (2012, pp. 119-

*Professor of Art History, Savannah College of Art and Design, USA. 
120). For Negri, this is an aesthetic act which must lead to a common will to transform society.

In fact, one of the commonalities between Beuys, Hardt and Negri is the idea that human consciousness must evolve in order to achieve a more equitable society and to reverse environmental damage. Beuys attempted to generate consciousness through his pre-linguistic actions such as in his 1967 performance Mainstream, described by Nat Trotman (2007, pp. 142-145) where Beuys crawled around the gallery floor, wiped fat over its surface, hopped around like a hare, formed fat corners on his body, and lined up molds along the gallery walls made by pressing fat into his mouth. Beuys occupied this Fat Room for ten hours, encompassing four hours of immobility where he stretched out on fat wedges until he the was fully charged like a battery. $\mathrm{He}$ then arose, inserted an antenna into a cone cast from wax and fat, and held it to his ear so that energy could flow from his head to the cone to counteract its cold, dead state. In this performance Beuys used his body as his medium to counteract the Law of Entropy, wherein "the warmth and energy of objects in the universe is emitted and then decreased until cold sets in, bringing about 'Kältetod' (Cold-death)," a process described by Antje von Graevenitz (Mesch \& Michely, 2007, p. 37).

Already by 1979 , Beuys saw the earth as being dead. As he proselytized, in an interview with Louwrien Wijers (Kuoni, 1990, pp. 245-252), only people can save the earth, since there is "no other spiritual being to do this work." When Beuys used a representation of a cross in his work, he stated that it was intended "as a symbol for earth... The vertical and the horizontal line of the construction of the cube... the crystallized condition of death...this crystalstructure of which every modern skyscraper is built..." (Kuoni, 1990, pp. 245252). In Cosmas and Damian, 1974 (Figure 1), Beuys labeled a postcard of the Twin Towers in New York with the names of two Byzantine healers, and signed it with his name. For Beuys, capitalism represents materialism that does not serve preservation of nature. To remind us of this wisdom, in Beuy's action 7,000 Oaks for Kassel, 1982 (Figure 2), each of the new oak trees was planted alongside a basalt column to stimulate an idea of a future world where responsibility for care of ourselves and the world will generate spirituality (De Domizio Durini, 2007, p.78). With the maturation of the trees after Beuys' death, the basalt columns at the foot of the trees read like tombstones warning of impending death unless the earth's air, water and soil are purged of pollutants.

Beuys states that "the problem of life, soul, humankind's spirit, the problems of intuition, imagination and inspiration....the problems of survival itself," are not symbolic, they are real (Kuoni, 1990, p.245). Also articulating reality, Negri voices the view that contemporaneity demands communication in the common through a multitude of events to force ethical decisions because "we are here, and we cannot escape to elsewhere" (Negri, 2012, p. 119) 
Figure 1. Joseph Beuys, Cosmas and Damian, 1974, Postcard

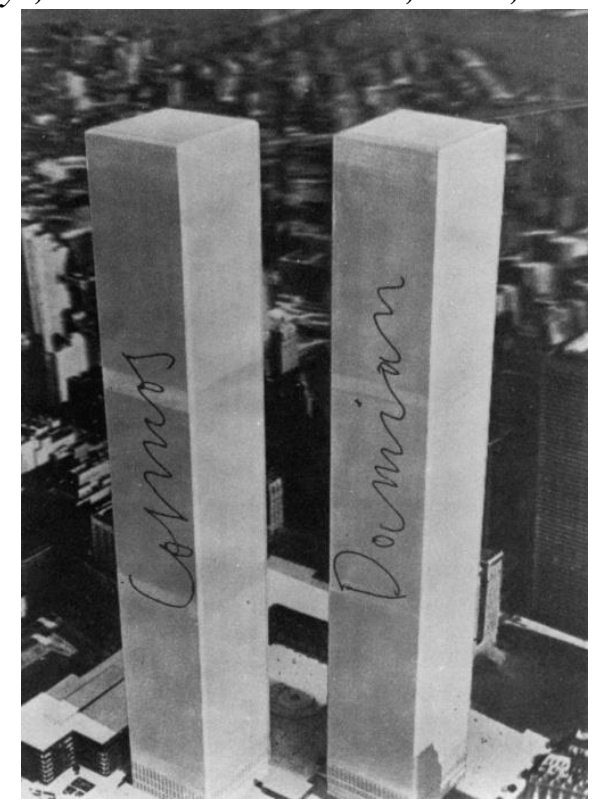

Figure 2. 7,000 Oaks for Kassel, 1982



Source: Joseph Beuys: The End of the 20th Century (Willisch \& Heimberg)

Thirty years after Beuys' provocation, the issues of economic justice and environmental attention have escalated. As reported by Wen Stephenson in The Nation, February 24, 2014 (pp.13-15), climate scientist James Hansen of the United States and a team of seventeen co-authors provided scientific information that "there is still opportunity for humanity to exercise free will," to reverse the damage of fossil fuels by moving to other sources of energy. Stephenson interviewed activist leaders in the youth climate movement in the U.S. who have led protests against tar sands pipelines and coal-fired power plants. Stephenson urges, "this shit is real...the prospects are not pretty current and future generations have to live through what's coming." 
For Stephenson, "merging of climate justice and economic democracy" can ignite the "sense of democratic possibility and grassroots power." $\mathrm{He}$ points out that Occupy Wall Street is a concrete example of "the sheer speed and unpredictability with which unrest can explode..." Arguably, visual art can ignite the explosion. The Occupy Wall Street campaign of 2011 was bolstered by an ADBUSTERS poster of a ballerina spiraling on top of the bronze bull on Wall Street, with the ghostly figures of anti-protest oppressors shading the background (Figure 3). The cover of The Nation, February 24, 2014 , co-opts the same dancer, who this time is atop a chimney blasting pollution from coal emissions. The image highlights a rally for economic and environmental justice staged at the Kentucky state capital (Stephenson, 2014, pp. 14-15). Beuys would have called this "biopolitical networking" SOCIAL SCULPTURE.

Figure 3. ADBUSTERS, Occupy Wall Street, 2011, Poster



Briefly, Beuys' Theory of Social Sculpture includes “THINKING FORMS - how we mold our thoughts; SPOKEN FORMS - how we shape our thoughts into words; and SOCIAL SCULPTURE - how we mold and shape the world in which we live: SCULPTURE AS AN EVOLUTIONARY PROCESS: EVERYONE AN ARTIST" (Kuoni, 1990, p. 19). Hardt and Negri advocate that the poor, who form the multitude, must will to think, to speak and to act autonomously as "a disobedient rebellious force that breaks through the fixity of the present and discovers the new" (2009, p. 17). Beuys' goal of an expanded art was to "to build A SOCIAL ORGANISM AS A WORK OF ART, since only then would democracy be fully realized....Self-determination and participation in the cultural sphere (freedom); in the structure of laws (democracy); and in the sphere of economics (socialism)" (Kuoni, 1990, p. 19). In this seeking after consciousness for everyone, Beuys' thought resonates with that of Hardt and Negri in their 2004 book Multitude: War and Democracy. In this book, they ponder if a new society can arise based on the biopolitical productivity of the multitude toward democracy, equality and freedom. For 
them, the term biopolitical encompasses the economic, the political, the social and the cultural. Hardt and Negri understand money as representing the social field of production under capitalism, and predict the death of capitalism and the formation of a new society formed through creative subjectivity.

These are the same principals that Beuys advocated in his Theory of Social Sculpture, including his own evolution from hermetic performances to open communication such as founding the Germany Student Party in Düsseldorf in 1967; speaking out against the Düsseldorf Academy's policy of limiting enrollment; establishing the Organization of Nonvoters to boycott elections for State Parliament in North Rhine-Westphalia in 1970; playing a key role in the Organization for Direct Democracy by Referendum in 1971 (with the direct message "Never vote for political parties again.)" As Beuys' former student Lukas Beckmann recounts (Ray, 2001, p. 100) the Environmental Protection Workgroup of the Organization for Direct Democracy organized a 'happening' in December 1971 in the Grafenberg Forest near Düsseldorf, whose message was "overcome the dictatorship of the political parties. Save the forest!"

Beuys tried to enact Direct Democracy at Documenta V in Kassel, 1972, when he spoke to the public for 100 days, initiating the idea of a Free International University (FIU). It was formalized the following year, with Beuys as the founding director of the Association for the Promotion of the Free International University for Creativity and Interdisciplinary Research located at the Academy in Düsseldorf. The goal was to remove education from state authority and as Beckmann puts it "address the design of all aspects of life and work" (Ray, 2001, p. 100).

Beckmann (Ray, 2001, pp. 98-111) provides the information that at Documenta VI in 1977, Beuys formalized the founding of the Free International University, integrating the Organization for Direct Democracy into the FIU (Figure 4). He spoke as a candidate for the European Parliament in Brussels in 1979; participated in the founding convention for the Green Party in Karlsrhule in 1980; and was lead singer for the rock group BAP's performance before 500,000 people of Sonne statt Reagan (Sun instead of Rain/Reagan) in Bonne on June 10, 1982. This demonstration, against deployment of nuclear missiles on German soil, coincided with U.S. President Ronald Reagan's visit to Bonn. Beuys' spoke on behalf of direct democracy in 1984, and wore himself out proselytizing about his ideas until his death, sometimes under the banner of the Greens. As Beckmann) recalls:

"Beuys provided important stimuli for the Greens...But did not view the Greens as a party in the traditional sense, rather as the expression of an emerging ecological age that had begun to understand the relationship between humanity and nature as a unit - a unity whose very existence on an international scale was threatened by the economics and lifestyle of humankind" (Ray, 2001, p. 108).

For Hardt and Negri (2009, pp. 296-305), in the new society that is forming, democracy will replace the hegemony of capital's control over labor 
power with biopolitical production to produce the common. How? Through the sheer joy of creativity. One of Beuys' slogans was "Creativity = Capital."

Figure 4. Joseph Beuys for Direct Democracy, 1972.



Source: Joseph Beuys Difesa Della Natura The Living Sculpture, Kassel 1977-Venice 2007, Tribute to Harald Szeemann, p. 131

\section{Pedagogy}

Cyberneticist Max Bense (1910-1990)) challenged Beuys in a televised 1970 interview to state how his provocation as an artist had caused a shift in consciousness. As documented (Pias, 2008, p. 113), Beuys replied, "I can only state that I tried as hard as possible to put something in my work that would cause a movement that changes consciousness." Pushed further by Bense, Beuys advocated pedagogy as the only way to lead people to concepts of humanity. In his teaching and in his social and political activism, Beuys sought a path towards healing not only his own psychic wounds but those of humanity. Delegated a professorship of sculpture at Düsseldorf Academy in 1961 (and dismissed in 1972), Beuys often stated that pedagogy was his most important role in society; to try to re-establish the balance in nature and equality for 
humanity in the economic and social spheres. Beuys explained to Achille Bonito Oliva, that the middle class discovered individual self interest and isolated itself from the working class, but "the next phase will include the whole of mankind in a process of education." (Kuono, 1990, p. 173)

In the same sense, Hardt and Negri (2009, pp. 308-309) demand mandatory global education for all, access to free and open networks, scientific research, open borders, and a minimum guaranteed income for all, regardless of whether people work. Calling for a "Seismic Retrofit: A Reformist Program for Capital," Hardt and Negri's analysis (2009, p. 306) demands repair of the environmental infrastructure to assure resources needed for survival. For these social theorists, the poor are the multitude who must will to think, speak, and act autonomously as "a disobedient, rebellious force that breaks through the fixity of the present and discovers the new" (2009, p. 17). Here Hardt and Negri are invoking Michel Foucault's "biopolitical plane of immanence," in Foucault's reading of Kant to discourse on how to "construct a democracy of the multitude" (2009, p. 21). They define "biopolitics" as the power of life to resist and determine an alternative production of subjectivity (2009, p.57). They surmise that:

"The biopolitical conception of the common permeates equally all spheres of life, referring not only to the earth, the air, the elements of even plant and animal life but also to the constitutive elements of human society, such as common languages/ habits, gestures, affects, codes, and so forth... an ecology of the common...focused equally on nature and society, on humans and the nonhuman world in a dynamic of interdependence, care and mutual transformation"

(Hardt \& Negri, 2009, p. 171).

Beuys' slogan, "Unity in Diversity," and his practice at documenta 5 in 1971 of debating with the public for 100 days, seems to correlate with the idea of Hardt and Negri of "a wide plurality of singularities in a common world," with a "focus on speech and communication" (2009, p. 174).

\section{Sunrise not "Twilight"}

A series of essays in a 2007 book, Joseph Beuys:The Reader intended to reopen "an international discussion on Joseph Beuys and his art" (Mesch \& Michely, 2007, p. 23). Editors Claudia Mesch and Viola Michely posit that "Beuys was one of the last western artists to take up the lineage of the engaged modernist avant-garde; this position had become almost unfashionable, even taboo, within postmodern art production in the USA" (Mesch \& Michel, 2007, p. 23). Beuys, though, dismissed postmodern art. As Beuys saw it, 
"...the whole idea of the post-modern boils down to a non-organic prolonging - a true metastasis - of something that belongs to the past... a comfortable way of trying to avoid the real problems that we are faced with...It is a way of attempting to egotistically exploit these problems rather than to solve them, and it does not provide any real insight or understanding." (De Domizio Durini, 2007, pp.78-79)

Notably, the demise of the postmodern ethos was heralded with the social turn in art, as documented in the book Living as Form, Socially Engaged Art from 1991-2011, edited by Nato Thompson (2012), and clearly signaled by Claire Bishop's award-winning book Artificial Hells, Participatory Art and the Politics of Spectatorship, of the same year. In what David Levi Strauss (1999) describes as Benjamin Buchloh's "hysterical trashing" of Beuys (Buchloh, 1980, pp.35-43; Buchloh et al., 1980, pp.3-21), Buchloh charges Beuys with mysticism. Already in a 1979 interview with Louwrien Wijers, Beuys speculated that a seeking of consciousness is misunderstood by some writers as mysticism (Kuoni, 1990, p. 242).

As explained to Wijers (Kuoni, 1990, p. 243), this confusion concerning his praxis stems from a kind of phenomenal radiation stemming from his objects. Buchloh interprets Beuys' use of fat, wax, felt, and hares' blood as an obsession, and Beuys' "interest in accumulating and combining quantities of rejected dusty old objects of the kind that one finds in rural cellars and stables," as anal compulsion. Buchloh condemns Beuys work as "a return to the repressed," and as outdated Surrealism (Buchloh, 1980, pp. 35-43; Buchloh, 1997).

Jacques Rancière has an opposite view. For Rancière, a political work must disrupt "the relationship between the visible, the sayable, and the thinkable without having to use the terms of a message as a vehicle... a rupture with the very logic of meaningful situations... a sensible or perceptual shock, caused, conversely, by the uncanny, by that which resists signification" (Rancière, 2011, p. 59). No doubt Beuys would agree. Beuys explained that his objects "are to be seen as stimulants for the transformation of the idea of sculpture...or of art in general. They should provoke thought about what sculpture can be and how the concept of sculpting can be extended to the invisible materials used by everyone" (Kuoni, 1990, p. 19). The "invisible forms" that Beuys invokes are imagination, inspiration and intuition (De Domizio Durini, 2007, p. 78).

In "Joseph Beuys at the Guggenheim", co-authored with Rosalind Krauss and Annette Michelson, Buchloh charges that Beuys' falsified his background. Incredulously, Buchloh seemingly does not understand that Beuys developed a persona to "perform Joseph Beuys." (Beuys' story is that he crashed his plane in the Crimea and was rescued and nurtured back to life by nomadic Tatars who wrapped him in fat and felt and transported him on a dog sled back to their camp to heal him. Thus, he was regenerated or reborn as the artist Joseph Beuys). Canadian artist Vera Frenkel thoughtfully speculates that: 
"With the help of the 'ahistoricity' to which Buchloh objects, Beuys allows others to project on him the attribute of benign leader, a sort of counter-Führer who makes the shit visible as opposed to endorsing the pathological cleanliness of the Nazi torture and murder machine..." (Mesch \& Michely, 2007, p.130)

Beyond the need to explain Joseph Beuys' art as arising out of trauma, there is the concept that humor can advance communication, particularly the coming together of people with a common will. With levity, but with conviction, in an interview with Willoughby Sharp (Kuoni, 1990, p. 81) Beuys stated that he formed a political party for animals (the largest party in the world). In The Chief, 1963-64, Beuys spent the length of a working day rolled up in felt with a dead hare at either end of his body, uttering incomprehensible sounds broadcast by speakers, seeking to advocate for the hares that could not speak for themselves. In 1968 at the Düsseldorf Academy, instead of a matriculation speech, Beuys emitted ten minutes of the cries of a stag without clean water to drink - an anarchistic action given the situation - at once humorous and profusely haunting (Tisdall, 1979, p. 266).

\section{Conclusion}

Just as Beuys felt that humans could shape the world through their thinking, their speech and their actions, Hardt and Negri wrote that "humans are trainable, that we can improve ourselves individually, collectively and over the course of history" (2004, p. 377). Elsewhere, Hardt and Negri argue for "joyful encounters with others, open paths to the imagination and capacities for action and passion" (2009, p. 379). How does this transpire? Like Beuys before them, Hardt and Negri stress that each person needs economic equity (at least the basic means to life and good health); everyone needs to learn how to think (access to free education for all); everyone should participate in democracy (self rule amongst equals). In Commonwealth (2009, p. 353), Hardt and Negri began to advocate a theory of revolution established by "an expanding web of others with whom to communicate and collaborate" (2009, p. 375). This action is to be shored up by common will, articulating "the singularities of the multitude...in a powerful and lasting common process" (2009, p. 375).

Beuys confided in a 1969 interview with Willoughby Sharp: "After I am dead, I would like people to say, "Beuys understood the historical situation. He altered the course of events. I hope in the right direction" (Kuoni, 1990, p. 92). The question is, can an impetus, set in motion by an artist, reignited by political theorists and activity in the common establish the will of the soon-to-come multitude? Beuys optimistically stated in his Expanded Concept of Art that man's productive and transformative energy "returns as future, as a total future, that of man becoming conscious, - free and autonomous in the achievement of his destiny as producer - self-producing at last" (Michaud, 1988, p. 46). As a survivor of World War II, Beuys suffered a mental breakdown and subsequent 
years of depression, where he actually spent days in his own crypt (Stachelhaus, 1987, pp. 47-53). Beuys realized that each human has to engage with the biopolitical or perish, so he climbed out of his coffin. Beuys is remembered for the phrase, "Everyone is an artist." Negri interprets cognitive labour as being artistic (2012, p. 117). Ergo, this supports Beuys' idea that since every person can think creatively, everyone is an artist. To paraphrase Negri (2012, p. 121), cognitive creativity leads to consciousness and the coming swarm of the multitude acting as a singularity.

\section{Bibliography}

Buchloh, B.H.D., 1980. Beuys: The Twilight of the Idol, Preliminary Notes for a Critique. Artforum, 5 (18), January, pp. 35-43.

Buchloh, B.H.D., Krauss, R., \& Michelson, A., 1980. Joseph Beuys at the Guggenheim. October, 12, Spring, pp. 3-21.

Buchloh, B.H.D., 1997. Joseph Beuys and Surrealism. Politics-Poetics Documenta X - the Book. Kassel: Cantz Verlag.

De Domizio Durini, L., 2007. Joseph Beuys, Difesta Della Natura: The Living Sculpture, Kassel 1977 Venice 2007, Tribute to Harald Szeemann. Milan: Silvano Editoriale.

Hardt, M., \& Negri, A., 2004. Multitude: War and Democracy in the Age of Empire. New York: The Penguin Press.

Hardt, M., \& Negri, A., 2009. Commonwealth. Cambridge, Massachusetts: The Belknap Press of Harvard University Press.

Kuoni, C., ed., 1990. Energy Plan for Western Man: Joseph Beuys in America, Writings by and Interviews with the Artist. New York: Four Walls Eight Windows.

Mesch, C., \& Michely, V., eds., 2007. Joseph Beuys: The Reader. Cambridge, MA: The MIT Press.

Michaud, E., 1988. The Ends of Art According to Beuys. Translated from French by R. Krauss. October, 45, Summer, pp.36-46.

Negri, A., 2012. Art and Multitude. Translated by E. Emery. Cambridge, U.K. and Malden, Massachusetts: Polity Press.

Pias, C., 2008. "Hollerith 'Feathered Crystal"": Art, Science, and Computing in the Era of Cybernetics. Grey Room, 29, Fall, pp.110-133.

Rancière, J., 2011. The Politics of Aesthetics. London, U.K. and New York: Bloomsbury Academic.

Ray, G., ed., 2001. Joseph Beuys: Mapping the Legacy. New York: Distributed Art Publishers in association with The John and Mable Ringling Museum of Art.

Stachelhaus, H., 1987. Joseph Beuys. Translated from German by David Britt. New York, London and Paris: Abbeville Press Publishers.

Stephenson, W., 2014. The Climate Democracy Project: How Do We Merge the Fights for Economic Justice and Climate Action. The Nation, February 24.

Strauss, D.L., 1999. American Beuys: 'I Like America \& America Likes Me'. In: Between Dog and Wolf. Essays on Art and Politics. Brooklyn, New York: Automedia. Also available online, from: http://johanhedback.com/beuys.html [Accessed: $28^{\text {th }}$ February 2015] 
Thompson, N., 2012. Living as Form: Socially Engaged Art from 1991-2011. New York: Creative Time Books and Cambridge, Massachusetts and London: The MIT Press.

Tisdall, C., 1979. Joseph Beuys. New York: Thames and Hudson, p.266.

Trotman, N., 2007. Ritual space/sculptural time. In: The Deutsche Guggenheim, Berlin. Beuys/Barney: All in the Present Must Be Transformed. New York: Distributed Art Publishers, $140 \mathrm{ff}$. 
